Danuta Przepiórkowska

Institute of Applied Linguistics, University of Warsaw danuta.przepiorkowska@gmail.com

\title{
Adapt or Perish: How Forced Transition \\ to Remote Simultaneous Interpreting during the COVID-19 Pandemic Affected Interpreters' Professional Practices
}

As the COVID-19 pandemic swept the world in late 2019 and throughout 2020, with subsequent countries introducing lockdown measures, the working realities of many occupations were upended. Simultaneous interpreters turned out to be perhaps the most affected profession in the language industry. This paper looks at one consequence of these developments: the forced transition to remote simultaneous interpreting (RSI). ${ }^{1}$

\section{Background}

As the pandemic threw people's lives into disarray, the only certain element of the new reality in 2020 was change. Some authors claim that the pandemic simply accelerated the social and technological change that was inevitable anyway [Stępowska 2020]. Since almost all multilingual

Throughout this paper, SI refers to 'simultaneous interpreting' and RSI refers to 'remote simultaneous interpreting.' 
in-person meetings, conferences, and other events were either cancelled or moved online, a need arose to study the changes in the interpreting profession. Various players in the language industry undertook ongoing efforts to diagnose the situation, among them professional organisations such as AIIC, ${ }^{2}$ the European Union Association of Translation Companies (EUATC) $)^{3}$ or FIT Europe, ${ }^{4}$ as well as research companies focusing on the language and localisation industry, e.g., $\mathrm{CSA}^{5}$ or Nimdzi. ${ }^{6}$ By the time this article was submitted, ${ }^{7}$ literature review revealed hardly any published academic research on the situation of interpreters during the pandemic (except Runcieman 2020 on community interpreting). The survey described in this article is an attempt to fill the existing gap, at least to a modest extent.

\section{Remote Interpreting and the Technological Turn}

In 2018, C. Fantinuoli wrote about the "upcoming technological turn" in interpreting studies [2018: 1], and this turn became a practical reality during the 2020 global pandemic. In Fantinuoli's view, two major technological breakthroughs had disruptive effects on the interpreting profession: i) the introduction of wired systems in speech transmission, leading to the rise of simultaneous interpreting, ii) the emergence of the Internet (although seen by this author mostly in the context of knowledge acquisition and preparation). Fantinuoli also anticipated the third breakthrough ('technological turn'), happening mostly in three areas: computer-assisted (CAI), remote (RI), and machine interpreting (MI) [2018: 2]. His remarks on remote simultaneous interpreting (RSI) were rather cautious and focused on economic considerations and depersonification while the scale of adoption of RSI platforms for home offices was unknown at the time [Fantinuoli 2018: 3].

\footnotetext{
2 https://aiic.org/uploaded/web/Interpreter\%20survey\%20report\%20FINAL.pdf [online] - 29.01.2021.

3 https://euatc.org/industry-surveys/2020-european-language-industry-survey-fullslide-set/ [online] - 29.01.2021.

4 http://fit-europe-rc.org/en/how-covid-19-is-impacting-independent-translationand-interpreting-professionals/ [online] - 29.01.2021.

5 https://csa-research.com/More/Featured-Content/Leadership-Resources/Freelancer2-Survey [online] - 29.01.2021.

6 https://www.nimdzi.com/interpreting-in-times-of-covid-19/ [online] - 29.01.2021.

7 Early 2021.
} 
However, the practice and academic reflection on remote interpreting dates back to a few decades ago. As Pöchhacker notes, experiments with electro-acoustic transmission systems for simultaneous interpreting started in 1920s (taking interpreters out of sight and putting them into 'remote' booths), experiments using satellite-based transmission date back to the 1970s while the arrival of the Internet, digital media and high data transmission capacities enabled web-based remote interpreting in video mode [2009: 138-139]. Previous research on the use remote interpreting in various settings and with the use of different technical means has been reviewed in a number of publications [e.g., Braun 2015, 2019; Ziegler and Gigliobianco 2018], focusing primarily on feasibility, working conditions, terminological and technological challenges.

There seems to be no commonly accepted definition of 'remote interpreting.' Shlesinger [2009] wrote about interpreters "working away from the meeting room" while a more recent, wider definition mentions interpreters being "in another room, building, city or country... linked to the primary participants by telephone or videoconference" [Braun 2015: 346]. Braun also makes a distinction between various settings (interpreters working from a hub, all participants in a single location, all participants in individual locations). The latter definition will prove most useful for this paper with the proviso that signal is transmitted over the Internet.

The notion of 'practices' in this paper draws on P. Bourdieu's sociological writings, which were popularised in translation and interpreting studies (T\&IS) with the arrival of the so-called 'sociological turn,' dating back to D. Simeoni's seminal paper on translator's habitus [1998]. 'Practice' is understood as repetitive human behaviours located in space and time [Jenkins 1992: 42]. To transform A. Chesterman's definition of 'practice of translation,' we assume that the practice of interpreting (in a given context) is made up of tasks whose performance takes place via interpreted events [Chesterman 2017: 317].

\section{Method and Survey Process}

\subsection{Research Questions and Target Group}

The purpose of the study was to provide an early diagnosis of simultaneous interpreters' practices in view of the radical change of circumstances during the 2020 global lockdown. The main research question was: How did 
the forced transition to remote simultaneous interpreting (RSI) during the COVID-19 pandemic affect interpreters' professional practices in the field of simultaneous interpreting? To answer this question, the survey questionnaire asked about the perceived degree of change, various adaptation strategies, and new experience during the pandemic, as well as the anticipated place of RSI in the respondents' professional life after the pandemic.

Since the lockdown periods and government restrictions in 2020 varied greatly from country to country, a decision was made to focus on interpreters based in/originating from Poland, with Polish as one of the working languages.

The study was exploratory in nature and, hence, no hypotheses were formulated beforehand.

\subsection{Research Method and Instrument}

In order to answer the research questions, a decision was made to conduct a survey in order to gather data on the changing practices and adaptation strategies during the pandemic. With this in mind, a questionnaire of 16 questions, divided into four parts, was designed:

Introduction - Description of target respondents (interpreters who offer simultaneous interpreting services), structure of the questionnaire, intended use of the results and technical details (incl. timing and assurance of anonymity).

Part I - Demographics and background (Q1. Gender, Q2. Age, Q3. Years of experience in simultaneous interpreting, Q4. Working languages).

Part II - Pre-pandemic and in-pandemic experience (Q5 Pre-pandemic experience of interpreting from home, Q6. Overall perception of changes in SI triggered by the pandemic, Q7. Actions taken to be able to perform RSI during the pandemic, Q8. Total expenditure on RSI-related adaptations, Q9-10. Experience of working in different interpreting setups during the pandemic, incl. new ones, Q11. Software tools used for RSI during the pandemic).

Part III - A 'personal letter' summarising the interpreter's relationship with RSI during 2020 (Q12. Positives, Q13. Negatives, Q14. Mixed feelings, Q15. The perceived future of RSI, Q16. Other comments).

Parts I and II contained closed questions, some allowing additional comments in a response option 'Other' (Q5-7, Q11) to capture the diversity of situations faced by interpreters under the new conditions. Part III was purposefully designed as a set of open-ended questions, enabling free 
expression of attitudes, description of experience, adaptation strategies and emotions triggered by the forced transition to RSI during the pandemic. The method was inspired by a study conducted by Kaisa Koskinen [2014], where she employed a Design Thinking tool known as 'Love Letter/Breakup Letter' [Hanington and Martin 2012: 114-115]. This article covers only responses to Q15, designed to capture interpreters' reflections about the future place and role of RSI in their professional practices.

\subsection{Survey Process and Timing}

The questionnaire was formulated in Polish and formatted with Google Forms. A survey invitation with a link was posted in the first half of January 2021 in three Facebook groups: Polscy Ttumacze Konferencyjni (Polish Conference Interpreters, 710 members on posting date), a closed group for members of the Polish Association of Conference Interpreters ${ }^{8}$ (63 members), and Ttumacze - Grupa Otwarta-Zlecenia dla Ttumaczy, the largest FB group/online platform for the Translation Industry in Poland (27,000 members). In addition, personalised invitations were sent to 194 interpreters from the author's personal database of contacts. The questionnaire remained available for 10 days.

The survey covers a period of exactly 10 months (from mid-March 2020, when lockdown measures were officially announced in Poland, to mid-January 2021, when the survey was conducted).

\subsection{Limitations of the Method}

Alongside numerous advantages (easy and quick completion, wide accessibility, convenient format of resultant raw data, etc.), the selected research method has a number of limitations, which should be borne in mind when looking at the findings.

Open-ended questions in a survey. Research has shown that generally, survey respondents are more reluctant to answer open-ended questions and tend to minimise the effort involved in completing a questionnaire [Bryman 2012: 247]. With interpreters as the target group, one could have expected that professionals working with spoken language could be reluctant to write at length, as opposed to translators [Koskinen 2014]. However, this did not turn out problematic in the present study as many

\footnotetext{
8 The author would like to extend her thanks to the Board of the Polish Association of Conference Interpreters (PSTK) for kindly agreeing to post the survey invitation in the closed Facebook group for PSTK members.
} 
respondents wrote extensively in response to open-ended questions (their answers reaching 60-80 words, with a record response of 492 words to one of the questions).

Self-completion. When respondents complete a survey by themselves, they may struggle with some questions or misinterpret their meaning. Also, the researcher has no control over who answers the questions [Bryman 2012: 235] and how many times. However, the latter is fairly unlikely [Hale and Napier 2013: 74] as the completion of a survey questionnaire requires both time and effort.

Representativeness. This survey does not claim to be representative and, in fact, no representative survey of simultaneous interpreters is possible since there exists no adequate sampling frame, i.e., a register of all simultaneous interpreters (e.g., with Polish as a working language). Such a sampling frame could only be constructed if a clear-cut definition of the target population existed. Therefore, neither probability sampling nor response rates could apply here [Bryman 2012: 674]. Instead, the present study relied on a working behavioural definition (the survey invitation was addressed at interpreters who offered simultaneous interpreting among their services). According to PSTK's estimates, ${ }^{9}$ the size of the professional community of simultaneous interpreters in Poland is closer to hundreds rather than thousands of members, which means that the findings can be seen as a relatively robust attempt at reflecting the pandemic experience of all simultaneous interpreters.

\section{Data Analysis}

The survey responses were downloaded from Google Forms into the MS Excel sheet format. The total number of responses received was 132, which can be considered as a fairly high figure given the short duration of the study and the fact that simultaneous interpreting is a niche area of practice in comparison, for instance, with translation. Each respondent was assigned a unique identifier (R001, R002... R132). The data for some variables were manually recoded in cases where input was heterogeneous (e.g. age given as a range, working languages entered as whole words versus two-letter symbols, expenditures given in different currencies or as ranges) to enable statistical analysis. Also, some new variables were

$\overline{9}$ Personal communication in January 2021. 
constructed on the basis of existing data in order to obtain further insights (e.g., respondents' age groups, experience in simultaneous interpreting during the pandemic: Yes/No).

The achieved number of responses was large enough to apply percentages and descriptive statistics in order to summarise and present quantitative descriptions of the collected dataset [O'Leary 2014; Saldanha and O’Brien 2014]. While questions Q1 to Q11 were originally designed to enable quantitative analysis, Q15 was open-ended and qualitative in nature. Therefore, it was possible to perform thematic analysis and open coding, and subsequent quantification [Bryman 2012: 249-251] using a spreadsheet and a word processor [Bree and Gallagher 2016].

\section{Findings}

\subsection{Respondents' Characteristics}

The essential demographic/professional characteristics of the respondents are described in the discussion and figures below.

Gender. The proportions in the effective sample, comprising 132 people, reflected the typical gender structure of the interpreting profession $\left(69 \%\right.$ of women vs. $31 \%$ of men $^{10}$ ) [cf. Gentile 2018].

Age and experience. The average age of the respondents was 44.6 years, with a median of 44 . The majority (75\%) were people aged $31-50$ (Figure 1). The average experience in simultaneous interpreting (in years) was 18.1, with a median of 17.5 years (Figure 2). These data mean that the sample largely consisted of individuals with an established professional position and a well-formed set of interpreting practices.

$\overline{10}$ One respondent chose 'other' in the question about gender. 
Figure 1

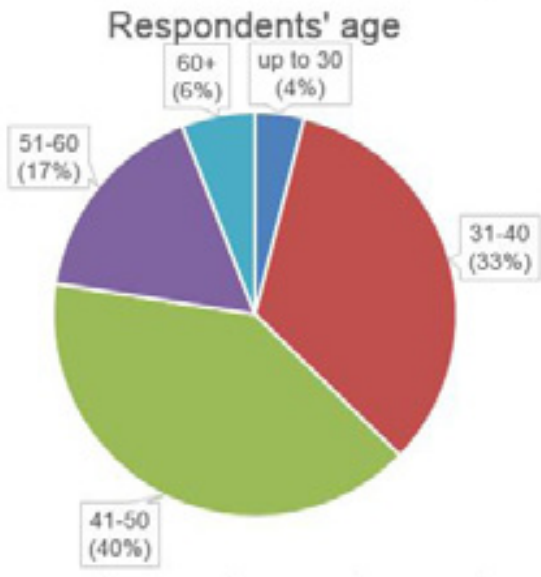

Figure 2

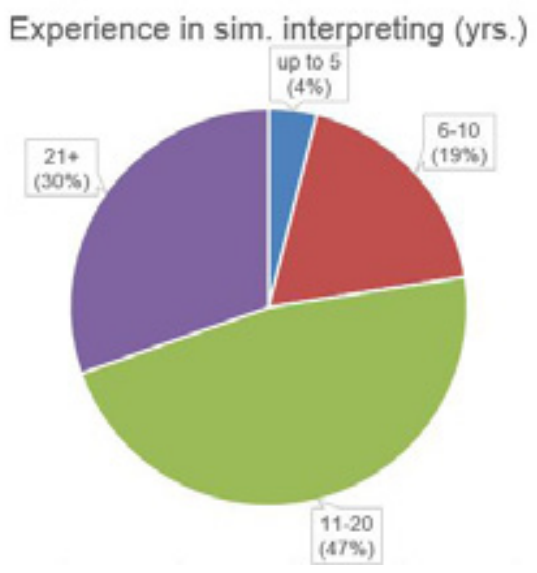

Working languages. All respondents had Polish in their language combination. Almost a half (48\%) had 2 working languages (including their mother tongue). There was also a very large group of interpreters (39\%) with 3 working languages. A total of $13 \%$ of the respondents offered 4 to 6 working languages (Figure 3 ). An overwhelming majority of the sample $(80 \%)$ offered English in their combination. The distribution of working 
languages is shown below (Figure 4). 'Other' languages included: Czech, Dutch, Polish Sign Language, and Portuguese (2 respondents each), as well as Hungarian, Norwegian, Romanian, Silesian, Slovak, and Swedish (1 respondent each).

\section{Figure 3}

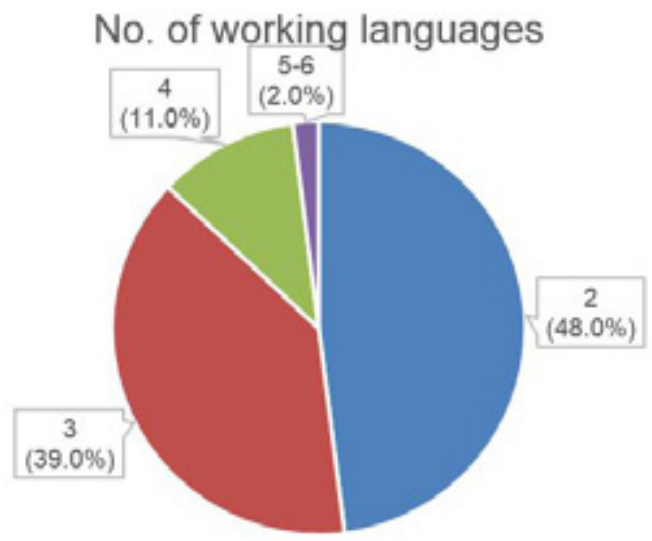

Figure 4

Working languages

(other than Polish), counts

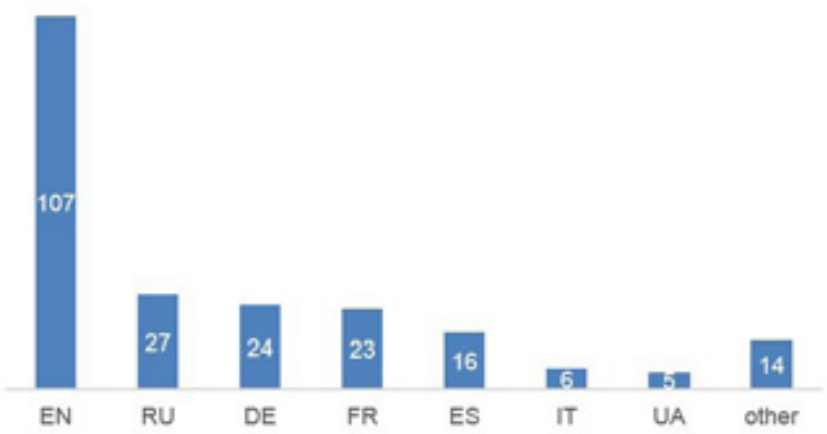




\subsection{Pre-pandemic Experience of Remote Interpreting from Home}

Since the shift to interpreting from home was among the major changes triggered by the lockdown measures, the respondents were first asked about their pre-pandemic experience of interpreting in this setting (as no mode was specified, some of that experience may have been consecutive). Contrary to expectations, slightly over a half of the respondents (54\%) did have some previous interpreting experience from home, which might suggest that the change in professional practices triggered by the new conditions may not have been quite so dramatic for this subgroup. As many as 40 respondents in the total sample (30.3\%) reported previous experience of interpreting from home via the Internet involving both audio and video signal, a setting which resembles the RSI setups commonly used during the pandemic. A detailed picture of the respondents' pre-pandemic experience of interpreting from home is shown in Figure 5.

Figure 5

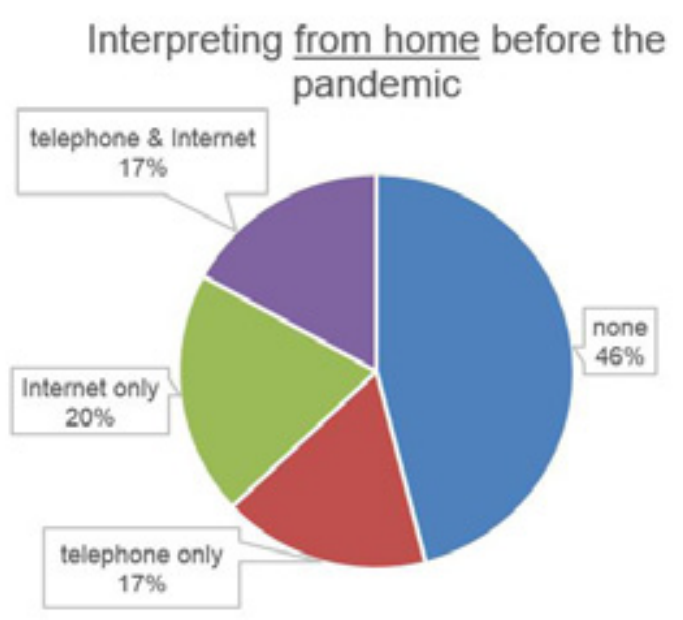

\subsection{Perceived Degree of Change Brought About by the Pandemic}

In Q6, the respondents were asked about the perceived degree of change in their simultaneous interpreting since mid-March 2020. The respondents who answered "I did not perform any simultaneous interpreting during the pandemic" were not included in the analysis of findings from this question. The distribution is shown below (Figure 6). 
Figure 6

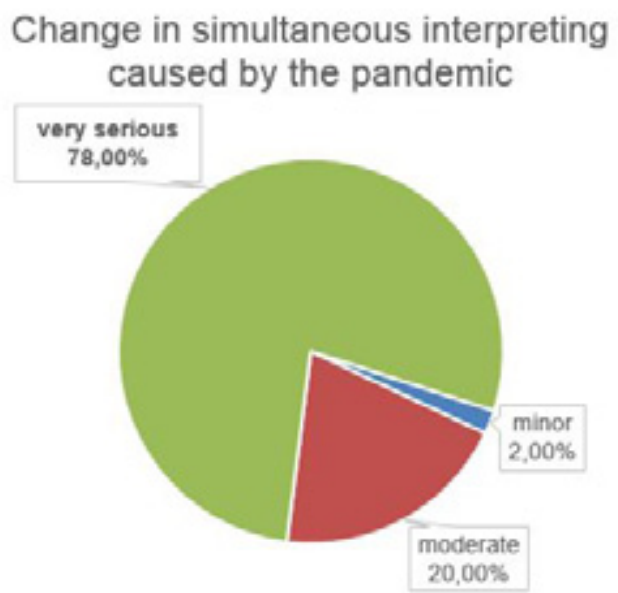

As may have been expected, the vast majority of the respondents (78\%) described the degree of change brought about by the pandemic in their simultaneous interpreting services as 'very serious.' This finding is in line with the prevailing view that the pandemic has revolutionised working conditions in the society [Brach and Lewicki 2020]. Interestingly, the change was rated as 'very serious' by the same proportion of interpreters $(4 / 5)$ in two groups: those with and without previous experience of interpreting from home. This suggests that pre-pandemic experience had been radically different and adaptations to RSI were required in 2020.

Only 26 interpreters felt the change was 'minor' or 'moderate.' More than a half of this group reported previous experience of interpreting from home via the Internet, which may be one possible reason, others worked for EU institutions so their overall work setting did not change radically: they continued working from the same geographical location and in the same booths, but with a changed booth composition (fewer interpreters per booth and/or social distancing measures applied ${ }^{11}$ ) and different sources of audio/video signal (most speakers connecting remotely from home).

11 One interpreter per booth, or the number of interpreters reduced from 3 to 2, with a plexiglass barrier installed. Source: FB page of DG for Interpretation, https://www.facebook.com/EUinterpreters/posts/1842528795889920 [online] - accessed 29.01.2021. 


\subsection{Efforts Made to Adapt to the New Circumstances}

Interpreters tend to adapt to new working conditions easily (although sometimes reluctantly) [Braun 2007; Shlesinger 2009] and this represents a firm part of their professional practice and habitus [e.g., Simeoni 1998; Inghilleri 2005].

This theoretical claim was confirmed in the survey findings. Only 7 respondents in the total sample (5\%) said they made no effort or arrangement enabling them to perform RSI during the pandemic. The remaining respondents reported various adaptative activities, even if they ultimately had no RSI assignments during the 10 months covered by the survey. The forced adaptation to the new working conditions came at a cost, both financial and non-financial.

Financial effort. As many as $76 \%$ of the respondents reported purchasing or acquiring equipment, hardware and/or software in order to be able to perform RSI. This reflects a serious change in working conditions: more than three quarters of established professionals were confronted with the need to make a sudden technological upgrade in order to be able to continue practicing their profession. The survey revealed that the expenses turned out to be affordable in most cases. In Q8, the respondents were asked to estimate the total amount spent in connection with the transition to RSI. The ranges of costs incurred in $\mathrm{PLN}^{12}$ are presented below (Figure 7). More than a half of the respondents (54\%) reported spending up to PLN 1000 (the lowest sum was PLN 80 to buy a headset with a microphone), which indicates that the transition to home-based RSI is financially feasible in the era of widespread access to computer technology and Internet. For as many as $19 \%$, the transition entailed no financial costs, which means that almost three quarters of the surveyed interpreters were able to make a fairly low-cost transition. Around $20 \%$ of those surveyed made more serious financial investments (PLN 1001-5000), e.g., buying studioquality equipment, another laptop for additional communication with booth partners or clients, installing a broadband Internet connection, etc. A handful of the respondents made still more considerable investments, sometimes to arrange a home-based studio, hub or additional technical capabilities (fibre-optic Internet line, UPS unit for power supply, etc.).

12 Costs provided in other currencies were converted to PLN at the National Bank of Poland's average exchange rate as of the date of response. 
Figure 7

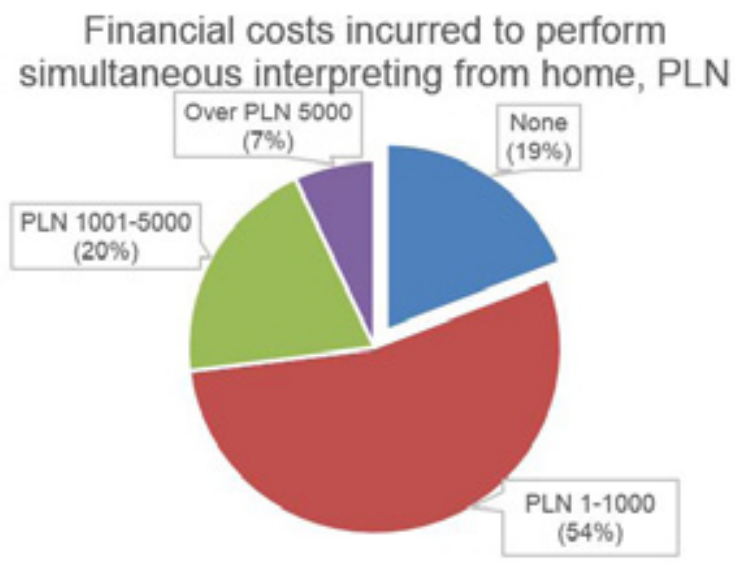

Organised education and self-study. Responses to Q8 revealed that the forced transition to RSI confronted many interpreters with the need to acquire new skills and knowledge to be able to practice their profession during the pandemic. Almost three quarters of the surveyed interpreters (73\%) participated in organised training/seminars devoted to RSI platforms, tools, and equipment configurations and also engaged in various forms of self-study (e.g., reading materials on RSI provided by $\mathrm{AIIC}^{13}$ or PSTK).

Peer-to-peer education. Simultaneous interpreting is not a solitary profession since it is predominantly performed in teams. Moreover, simultaneous interpreters work with multiple booth partners in the course of their careers. Hence, they represent a highly networked professional community (presumably even more so than translators [cf. Risku and Dickinson 2017]). This fact turned out to be an important resource, helping interpreters to make a transition to RSI. In order to be able to perform RSI during the pandemic, the largest proportion of the respondents $(82 \%)$ resorted to networking: they sought information on RSI from other interpreters via conversations, social media, etc. An impressive proportion (56\%) shared their own knowledge and experience with colleagues (via personal communication and social media). These figures reflect the extremely high

13 International Association of Conference Interpreters (https://aiic.org/). 
need for support in the face of the radically changed working conditions as well as high solidarity within this networked profession.

Home office. Some interpreters, especially those who also work as translators or who had interpreted from home before 2020, already had home office arrangements before the lockdown. Others, however, only used their homes as a place to prepare for interpreting assignments. Lockdown measures, however, forced everyone, including simultaneous interpreters, to stay at home and make work-related adaptations [Brach and Lewicki 2020]. In addition to the aforementioned purchases of hardware and software, other arrangements were also required. As many as 39\% of the respondents made some physical adaptations in their homes to be able to perform RSI (e.g., delineating a dedicated area of the house, or even undertaking a major overhaul), while $24 \%$ had to negotiate working times and acoustic conditions (as schools were closed, many interpreters had to perform RSI from home with their children present, others negotiated 'quiet time' with their family and neighbours, etc.).

Interactions with clients. For most participating interpreters, the new practice of RSI performed from home evolved into a separate service in their portfolio, encouraging new interactions with clients. Well over a half of the respondents (58\%) let their existing clients know about adding remote interpreting services to their portfolio (these interactions often involved time-consuming client education). More than 1/5 saw the new circumstances not only as problematic, with the accompanying costs and extra effort required, but also as a new business opportunity: $21 \%$ felt sufficiently comfortable about the new skills and setups to seek new clients for RSI.

Overall, the 10 months of the pandemic enforced a wide array of adaptation efforts. A summary of various activities undertaken by interpreters during the lockdown in order to ensure continuity of professional practice during the COVID-19 pandemic is presented in Figure 8. 
Figure 8

\section{Efforts made to perform RSI during the pandemic}

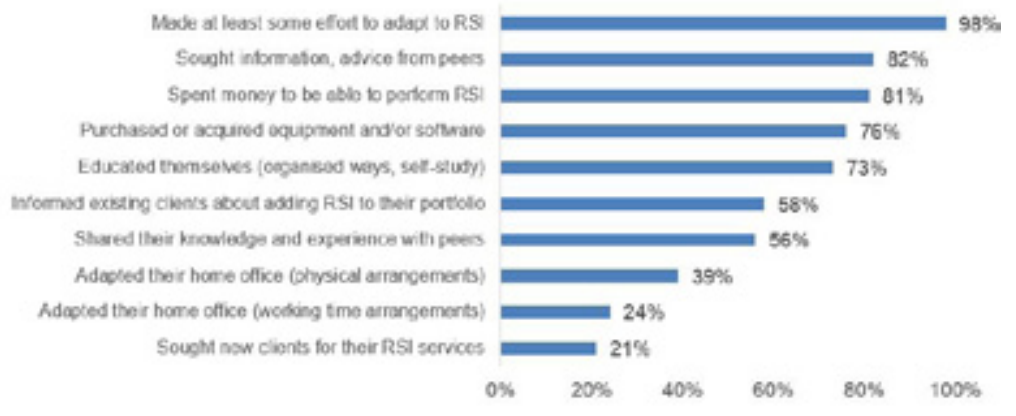

\subsection{Shifts and Adaptations in Working Modes and Tools}

As mentioned earlier, the 2020 lockdown measures triggered the emergence of new working configurations, forcing simultaneous interpreters to adapt accordingly. While a considerable share of interpreters in the sample had some experience of interpreting from home before 2020 (see section 5.2 ), as many as $78 \%$ of the respondents nevertheless felt that the pandemic caused 'very serious' changes to how they performed simultaneous interpreting. Presumably, the tools and setups before and during the pandemic were significantly different (a topic that requires further study). This survey casts some light on the most important shifts and adaptations.

Setups. Two setups turned out to be particularly common in interpreters' pandemic experience: $48 \%$ of all those surveyed debuted in a setup where they were at home while their booth partner was in a different location, while $45 \%$ had their first-time experience in working in an RSI hub (social distancing, hybrid events). 36\% worked from home together with a booth partner for the first time, whereas $25 \%$ debuted in short solo RSI assignments from home. The reported percentages can be viewed as tokens of considerable adaptation efforts.

Tools. The sample consisted of seasoned professionals, well-versed in working tools of traditional conference settings. Nevertheless, the transition to web-based RSI required them to learn new software tools and make new 'debuts' in the familiar job. The types of tools included: a) dedicated interpreting platforms (e.g., Interprefy, Kudo, Voiceboxer, Interactio), b) popular remote conferencing software (e.g., Zoom, Microsoft Teams, 
Webex), c) well-known messaging apps normally used for other purposes but, in the case of RSI, providing an additional channel of communication between booth partners (e.g., Skype, WhatsApp, Facebook Messenger), d) other apps for extra functions, such as shift timing.

Zoom, a popular software tool for remote conferencing in business, academia and other settings, significantly outperformed other instruments in terms of usage frequency for RSI in the surveyed sample. One reason was that it had launched the language interpretation feature even before the pandemic and kept adding new language options throughout 2020. A total of $87 \%$ of the respondents interpreted via Zoom ( $79 \%$ for the first time during the pandemic). Only $13 \%$ had never tried this tool for RSI. Microsoft Teams was the second most popular platform (presumably due to its widespread use by institutions and businesses), although it offers no interpretation feature and must be used in combination with other communication tools. Despite this limitation, as many as $55 \%$ of the respondents reported using MS Teams for RSI ( $48 \%$ for the first time during the pandemic). WhatsApp, the messaging tool, turned out to be the third most popular solution in RSI: $45 \%$ of the respondents ever used it for interpreting (33\% for the first time in RSI during the pandemic).

The survey found that dedicated RSI platforms, with features that enable them to handle complex interpreted events (multiple languages, relay, multi-party chat), did not gain very high significance during the pandemic. Only $22 \%, 18 \%$, and $12 \%$ of the respondents said they used Interprefy, Kudo, and Voiceboxer, respectively, for the first time during the pandemic, with Interprefy enjoying by far the highest exposure rates (a total of 22.5\% of the respondents had any experience with it, before or during the pandemic). Possible reasons may be related to considerable costs charged by these platforms and the fact that while they offer relative comfort to interpreters, added value for other meeting participants is not easily visible (as compared to popular remote conferencing solutions).

In addition, 12 respondents mentioned Interactio (a RSI platform used by the EU institutions). More than a quarter (26.5\%) mentioned other software tools for RSI (however, this area calls for further exploration).

This section has demonstrated how the pandemic forced simultaneous interpreters to acquire new skills and adapt to different setups and tools, sometimes within a very short time. A summary of the respondents' firsttime experience in RSI during the pandemic is given in Figure 9. 
Figure 9

\section{First-time experience in RSI during the pandemic}

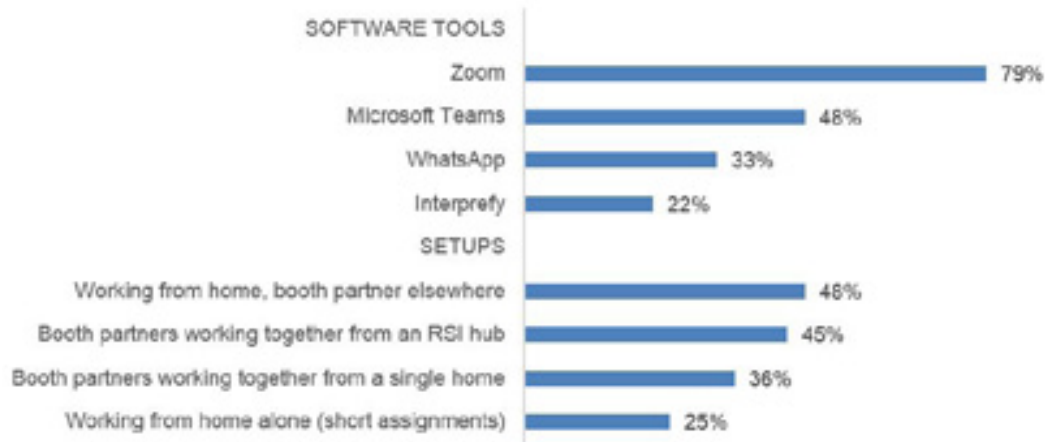

\subsection{The Future of RSI}

In Q15 (open-ended), the respondents were asked about the expected role of RSI in their future professional lives. All answers were first coded and then quantified.

As many as $88 \%$ of the surveyed interpreters felt that RSI had become so firmly embedded in the 'new normal' that it would become a regular element of their professional practice. Only $6 \%$ were sure that RSI would disappear from their lives, while another $6 \%$ did not provide a firm answer (Figure 10). This indicates that the 10 months of the pandemic were sufficient to establish new and stable elements of professional practice, evolving into a collective 'feel for the game' [Inghilleri 2005: 15]. 
Figure 10

\section{Opinions on the future of RSI in respondents' professional practice}

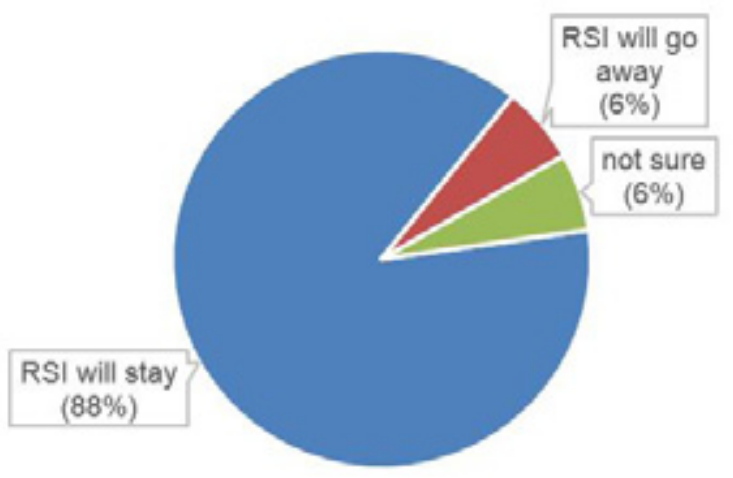

As regards the preferred future 'relationship with RSI,' $6 \%$ of the respondents had no opinion or remained neutral, while over a half (52\%) were open to incorporating RSI as a regular part of their professional practice (with $27 \%$ preferring a mix of on-site and remote mode). While $22 \%$ rejected RSI and strongly preferred going back to in-situ SI, approximately one third (32\%) reluctantly accepted RSI as a new addition to their professional repertoire, believing they had no other choice. The distribution of reported attitudes is shown in Figure 11. 
Figure 11

\section{Attitudes towards incorporating RSI into one's own professional practice}

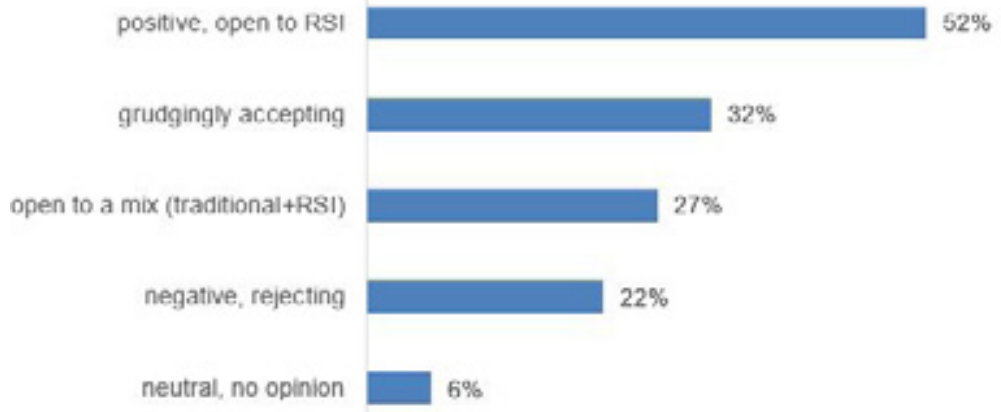

\section{Conclusions and Suggestions for Further Research}

The survey findings have shown that the COVID-19 pandemic indeed triggered numerous changes in interpreters' professional practices, forcing them to adapt by learning new skills, arranging their own working space, and engaging in intensive exchanges with peers and clients. 'Adapt or perish' can, indeed, be seen as a motto of these efforts, especially given that approximately a half of the surveyed respondents reported reluctant or negative attitudes and felt forced to adapt. This echoes Simeoni's claim that most translating (here: interpreting) agents "exert their activity in fields where their degree of control is nil or negligible" [Simeoni 1998: 14]. Thus, as may have been expected, interpreters resorted to intensive networking and demonstrated high solidarity as a coping strategy. Based on the judgments expressed after ten months of the pandemic, most surveyed interpreters believe that remote interpreting will become a regular part of their professional practices.

This survey study attempted to offer early findings in this new, vast area of exploration. Further studies are needed to explore the significant changes in the interpreting profession following the COVID-19 crisis, e.g., studies focused on product and performance (e.g., quality), process (incl. 
cognitive effort, stress, fatigue, etc.), new roles (e.g., interpreters as technology consultants), or ethnographic research on working from home, to name just a few ideas. It is hoped that the findings presented in this paper will make a useful contribution to the exploration of the new realities of the interpreting profession.

\section{Bibliography}

Brach, B., Lewicki, M. (2020), "Flow, płaczące dzieci i dziesięcioręki budda o pracy z domu w czasach pandemii", online presentation during the $21 \mathrm{st}$ Congress of Market and Opinion Researchers [online] https://kongresbadaczy.pl/2020_program/flow-placzace-dzieci-i-dziesiecioreki-budda-o-pracyz-domu-w-czasach-pandemii/ - 02.02.2021. ${ }^{14}$

Braun, S. (2007), "Interpreting in small-group bilingual videoconferences: Challenges and adaptation processes", Interpreting. 9(1): 21-46, https://doi. org/10.1075/intp.9.1.03bra.

Braun, S. (2015), "Remote interpreting", [in:] Franz Pöchhacker (ed.), Routledge Encyclopedia of Interpreting Studies, Routledge, London-New York: 346-348, https://doi.org/10.4324/9781315311258-16.

Braun, S. (2019), “Technology and Interpreting”, [in:] Minako O’Hagan (ed.), Routledge Handbook of Translation and Technology, Routledge, London: 271-288.

Bree, R., Gallagher, G. (2016), "Using Microsoft Excel to code and thematically analyse qualitative data: A simple, cost-effective approach", All Ireland Journal of Teaching and Learning in Higher Education - AISHE-J. 8(2): 2811-2819.

Bryman, A. (2012), Social Research Methods, Oxford University Press, Oxford. Chesterman, A. (2017), Reflections on Translation Theory: Selected Papers 19932014, John Benjamins, Amsterdam, https://doi.org/10.1075/btl.132.

Fantinuoli, C. (2018), "Interpreting and Technology: The upcoming technological turn", [in:] Claudio Fantinuoli (ed.), Interpreting and Technology. (Translation and Multilingual Natural Language Processing 11), Language Science Press, Berlin: 1-12.

Gentile, P. (2018), “Through women's eyes. Conference interpreters' self-perceived status in a gendered perspective", Hermes - Journal of Language and Communication in Business. 58: 19-42, https://doi.org/10.7146/hjlcb.v0i58.111658.

14 The author would like to thank the Polish Society of Market and Opinion Researchers (PTBRiO) for enabling access to the video-recorded conference presentation. 
Hale, S., Napier, J. (2013), Research Methods in Interpreting. A Practical Resource, Bloomsbury Academic, London-New York-New Delhi-Sydney.

Hanington, B., Martin, B. (2012), Universal Methods of Design. 100 Ways to Research Complex Problems, Develop Innovative Ideas, and Design Effective Solutions, Rockport Publishers, Beverly.

Inghilleri, M. (2005), "Mediating Zones of Uncertainty. Interpreter Agency, the Interpreting Habitus and Political Asylum Adjudication", The Translator. 11(1): 69-85, https://doi.org/10.1080/13556509.2005.10799190.

Jenkins, R. (1992), Pierre Bourdieu. Key Sociologists, Routledge, London-New York.

Koskinen, K. (2014), "Kääntäjän habitus fiktiivisten rakkaus- ja erokirjeiden valossa", MikaEL Kääntämisen ja tulkkauksen tutkimuksen symposiumin verkkojulkaisu. Electronic proceedings of the KäTu symposium on translation and interpreting studies, Vol. 8, [online] https://www.sktl.fi/@Bin/533357/Koskinen_MikaEL2014\%20(1).pdf-10.01.2021.

O'Leary, Z. (2014), The essential guide to doing your research project (2nd ed.), SAGE, London.

Pöchhacker, F. (2009), "Issues in Interpreting Studies”, [in:] Jeremy Munday (ed.), The Routledge Companion to Translation Studies, Routledge, London-New York, pp. 128-140.

Risku, H., Dickinson, A. (2017), "Translators as Networkers: The role of virtual communities", Hermes - Journal of Language and Communication in Business. (42): 49-70, https://doi.org/10.7146/hjlcb.v22i42.96846.

Runcieman, A.J. (2020), "Community interpreting and the COVID-19 crisis: Present relevancy and future directions", Tilburg Papers in Culture Studies. 242, [online] https://www.tilburguniversity.edu/sites/default/files/download/TPCS_242-Runcieman.pdf-30.01.2021.

Saldanha, G., O’Brien, S. (2014), Research Methodologies in Translation Studies, Routledge, London-New York, https://doi.org/10.4324/9781315760100.

Shlesinger, M. (2009), "Crossing the divide: What researchers and practitioner can learn from one another", Translation \& Interpreting. 1(1): 1-14.

Simeoni, D. (1998), “The pivotal status of translator's habitus", Target. 10(1): 1-39.

Stępowska, D. (2020), “Technologia cyfrowa - narzędzie do wspomagania i jednoczesnej dekoncentracji w czasie pandemii COVID-19", [in:] Krzysztof Marcinkiewicz, Paweł Nowak, Dominika Popielec, Magdalena Wilk, (eds.), Koronawirus wyzwaniem wspótczesnego społeczeństwa. Media i komunikacja 
społeczna, Polskie Towarzystwo Komunikacji Społecznej, Kraków-Wrocław, pp. 133-149.

Ziegler, K., Gigliobianco, S. (2018), "Present? Remote? Remotely present! New technological approaches to remote simultaneous conference interpreting", [in:] Claudio Fantinuoli (ed.), Interpreting and Technology. (Translation and Multilingual Natural Language Processing 11), Language Science Press, Berlin, pp. 119-139.

\begin{abstract}
This article discusses the results of a survey carried out among 132 simultaneous interpreters with Polish as their working language, summarising their professional experience during the first 10 months of the COVID-19 pandemic. In the context of the forced transition to the remote mode of simultaneous interpreting and the related technical and organisational challenges, this survey captured the early experience of working remotely (mostly from home), as well as the adaptations necessitated by the new situation in terms of changes in working modalities and tools, particularly in the home environment. The article also presents the surveyed interpreters' expectations regarding the role and place of remote simultaneous interpreting in their future professional practices.
\end{abstract}

Keywords: remote simultaneous interpreting, RSI, interpreters, COVID-19 pandemic, technological turn, professional practices

\begin{abstract}
Abstrakt
Dostosuj się albo zgiń: Jak przymusowe przejście na zdalne thumaczenie symultaniczne (RSI) w czasie pandemii COVID-19 wpłynęło na praktykę zawodową tlumaczy ustnych

W niniejszym artykule omówiono wyniki badania ilościowego zrealizowanego wśród 132 tłumaczy symultanicznych pracujących z językiem polskim, podsumowującego ich doświadczenia zawodowe z okresu pierwszych 10 miesięcy pandemii COVID-19. W kontekście przymusowego przejścia na tryb zdalny tłumaczenia symultanicznego oraz związanych z tym wyzwań technicznych i organizacyjnych zbadano wczesne doświadczenia pracy zdalnej (głównie z domu) oraz wymuszone nową sytuacją
\end{abstract}


dostosowania w zakresie trybu i narzędzi pracy, w szczególności w otoczeniu domowym. W artykule przedstawiono również przewidywania badanych tłumaczy na temat roli zdalnego thumaczenia symultanicznego w ich przyszłej działalności zawodowej.

Słowa kluczowe: zdalne thumaczenie symultaniczne, RSI, thumacze ustni, pandemia COVID-19, zwrot technologiczny, praktyka 